\title{
Financial development and prehistoric geographical isolation: global evidence
}

\author{
OASIS KODILA-TEDIKA, ${ }^{\star}$ SIMPLICE A. ASONGU, \\ MATTHIAS CINYABUGUMA ${ }^{\star \star \star}$ and \\ VANESSA S. TCHAMYOU ${ }^{\star \star \star \star}$ \\ *University of Kinshasa \\ **African Governance and Development Institute, University of Cape Town and Covenant University \\ $\star \star \star$ The World Bank Group \\ $\star \star \star \star A$ African Governance and Development Institute and University of Antwerp
}

\begin{abstract}
Using cross-country differences in the degree of isolation before the advent of technologies in sea and air transportation, we assess the relationship between geographical isolation and financial development across the globe. We find that prehistoric geographical isolation has been beneficial to development because it has contributed to contemporary cross-country differences in financial intermediary development. The relationship is robust to alternative samples, different estimation techniques, outliers and varying conditioning information sets. The established positive relationship between geographical isolation and financial intermediary development does not significantly extend to stock market development.
\end{abstract}

Keywords: financial development, isolation, agglomeration, globalisation

JEL classification: $\mathrm{F}_{5} 5, \mathrm{G}_{5} 5, \mathrm{~N}_{7}, \mathrm{O}_{16} 6 \mathrm{O}_{50}$

Is geographical isolation related to development outcomes such as financial development? To the best of our knowledge, the answer to this question is missing in empirical literature. Various aspects of financial development to explain its relative presence or absence have been explored over the past decades, notably: theories related to credit information and power (Stieglitz and Weiss I98 I; Aghion and Bolton 1992;

O. Kodila-Tedika, Department of Economics, University of Kinshasa, Democratic Republic of the Congo; S. A. Asongu (corresponding author), African Governance and Development Institute, PO Box 84I3, Yaoundé, Cameroon; Department of Economics and Development Studies, Covenant University, Ota, Ogun State, Nigeria; and Development Finance Centre, Graduate School of Business, University of Cape Town, Cape Town, South Africa; e-mail: asongusimplice@yahoo.com. M. Cinyabuguma, Department of Social Development, The World Bank Group, Washington, DC, USA; V. S. Tchamyou, African Governance and Development Institute, and Faculty of Applied Economics, University of Antwerp, Belgium. We thank James B. Ang, who supplied us most of the data used in this research. We are also grateful to the journal's anonymous referees for their helpful comments and suggestions. The usual disclaimer applies. 
Djankov et al. 2007; Tchamyou and Asongu 20I7); theory of law and finance (La Porta et al. I997; Beck et al. 2003); culture (Stulz and Williamson 2003; KodilaTedika and Asongu 20I5a); abuse of market power and competition in the banking sector (Coccorese and Pellecchia 20IO; Coccorese 20I2); globalisation (Asongu 20I4; Asongu and De Moor 20I7); remittances (Osabuohien and Efobi 2013; Efobi et al. 2015); endowment theory (Beck et al. 2003); the role of the state (Rajan and Zingale 2003; Becerra et al. 20I2; Ang 20I3a); genetic distance (Ang and Kumar 20I4); macro-finance (Rajan and Zingales I998; Baltagi et al. 2009); social capital (Guiso et al. 2004) and human capital (Kodila-Tedika and Asongu 20 I 5 b).

The study closest to the present inquiry is Ashraf et al. (20 I0), which has examined how cross-country differences in the degree of prehistoric geographical isolation affect the contemporary development process with respect to income per capita. The authors have also been motivated by the absence of studies that examine the relationship between prehistoric isolation and contemporary development outcomes. Existing studies on comparative development have emphasised a plethora of ultimate and proximate characteristics underpinning some of the substantial disparities in standards of living across the globe. The relevance of cultural, institutional, geographical and religious fractionalisation, as well as linguistic, ethnic, globalisation and colonisation features, have motivated the debate on the timing of differential economic growth from stagnation to modern growth over the past 200 years. According to Ashraf et al. (2010), whereas the underlying factors have been investigated from the perspective of contemporary effects, less attention has been paid to prehistoric characteristics that have affected contemporary development and cross-country differences in economic growth.

The motivation for assessing the nexus between geographical isolation and economic development builds on the intuition that globalisation has been documented to affect the development process, through inter alia: trade (Musila and Sigué 20Io); capital flows (Price and Elu 20I4; Motelle and Biekpe 20I5); foreign aid (KayizziMugerwa 200I; Obeng-Odoom 20I3) and technological diffusion (Tchamyou 20I6). According to Ashraf et al. (2010), the reduced ability of societies that are geographically isolated to gain from progress in global technological frontiers could have compelled independent advancements in technological progress, therefore inducing a fundamental cultural setting that is favourable to innovation and development. Furthermore, geographically isolated societies might have benefited from the diminished threat of predation, which logically fostered efficient allocation of resources towards development outcomes and protected property rights, ultimately contributing to the setting of fundamental cultural values that are beneficial to economic development.

In the light of the fact that geographical isolation promoted a fundamental and persistent cultural environment that enhanced development, it is plausible to infer that prehistoric geographical isolation has played a significant role in the development process, hence, influencing contemporary development across the world. 
This study exploits prehistoric cross-country differences in geographical isolation in order to assess its effect on financial development across the globe. Ashraf et al. (2010) consider prehistoric geographical isolation prior to the advent of airborne and seafaring technologies of transportation as proximate and ultimate causes underlying some of the cross-country differences in living standards across the globe. We find that prehistoric geographical isolation has had a significant positive relationship with the process of development because it has contributed to contemporary crosscountry differences in financial development. The relationship is robust to alternative samples, different estimation techniques, outliers and varying conditioning information sets. The relationship between isolation and financial development is depicted in Figure I.

The rest of the study is structured as follows. Section I discusses the theoretical underpinnings of the relationship between openness and development. The data and methodology are outlined in Section II. Section III presents empirical results, while Section IV covers robustness assessments. Concluding implications and future research directions are provided in Section v.

There are two principal theoretical bases for the relationship between openness and development, notably: the neoliberal view and the hegemony perspective (see Tsai 2006; Asongu 20I3). First, the neoliberal strand of openness argues that openness is an instrument of 'creative destruction' in the perspective that technological innovation, global trade and cross-border investment enhance efficiency in production and engender substantial progress in spite of job substitution and falling wages for workers that are unskilled. According to the narrative, the drawbacks of openness are assuaged by requesting workers that are unskilled to improve on their knowhow in order to gain from the positive externalities of increasing openness. According to Grennes (2003), such benefits can be rewarding to the population if the labour market is influenced by 'supply and demand'.

Second, with regard to the hegemonic strand, policies favouring global openness are hidden projects that are designed to create a new world order which will be under the control of global financial institutions and developed countries. This school of thought maintains that openness encourages the accumulation of capital, growing inequality and extension of rewards of trade in goods and services to trade in financial assets. Proponents of this stream predict 'a world-wide crisis of living standards for labor', granting that the capital accumulation process has been borne by the working class because 'technological change and economic reconversion endemic to capitalist development has generated an enormous growing pool of surplus labor, an industrial reserve army with incomes at or below the level of subsistence' (Petras and Veltmeyer 200 I, p. 24).

Another dimension of the hegemonic view maintains that production modes of neoliberal policies are connected to a process of dynamic production which 
undermines redistribution channels that are consistent with Keynesian social democracy. According to some narratives in this strand, global openness favours the quest for private gains to the detriment of more ethical values like inclusive development (Smar 2003) and environmental protection (Obeng-Odoom 20 I 5). Furthermore, the redistribution process of benefits from openness is skewed in favour of the faction of the population that is already in privileged socio-economic positions (Scholte 2000). Though from a less radical perspective, Scholte's position is shared by Sirgy et al. (2004).

The decision on whether a country should adopt openness policies in view of stimulating domestic financial development remains open to debate in the literature (Asongu and De Moor 20I7). Asongu (2014) provides two perspectives on the importance of openness in financial development.

The first perspective on allocation efficiency, which is based on theoretical underpinnings of the neoclassical growth model from Solow (I956), considers that openness eases the efficient allocation of resources at the international level. Those that hold this view maintain that capital resources (which in part simulate financial development) will flow from countries in which capital is abundant to countries in which capital is scarce. In capital-scarce countries, positive rewards include externalities that are essential to raise standards of living, among others: increased investment, reduced capital cost and growth that is pro-poor (see Fischer I998; Obstfeld I998; Rogoff I999; Summers 2000; Batuo and Asongu 2015). Over the past decades, many countries have justified the need for more openness with such potential rewards.

Conversely, another strand of the literature maintains that the arguments of allocation efficiency in resources are a fanciful attempt to extend gains from international trade in commodities to international trade in assets. With regard to this sceptical view, the rewards of allocation efficiency are feasible if and only if the transfer of international resources is not characterised by volatilities. Hence, as argued in recent literature (Rodrik I998; Rodrik and Subramanian 2009; Batuo and Asongu 20 I 5), in the light of volatilities that have been experienced by some countries, the theoretical foundations of allocation efficiency may not reflect practical reality. In this light, the pessimistic opinions are best articulated by Rodrik (I998) and Rodrik and Subramanian (2009), with respective titles like 'Who Needs Capital-Account Convertibility?' and 'Why Did Financial Globalization Disappoint?' For instance, Rodrik (I998) maintains that there is no nexus between openness and the level of 'growth and investment' in developing nations. He articulates that whereas it is difficult to establish the benefits of capital account openness, the costs of financial openness are growingly apparent through financial crises that are increasing in terms of frequency and magnitude. Rodrik and Subramanian (2009) have established that the subprime mortgage crisis, which resulted in the global financial crisis, has raised doubts about the net development benefits of growing financial openness.

Dornbusch (I996) considered capital controls as 'an idea whose time had past' and reaffirmed his position two years later that 'the correct answer to the question of capital mobility is that it ought to be unrestricted' (Dornbusch I998, p. 20), while 


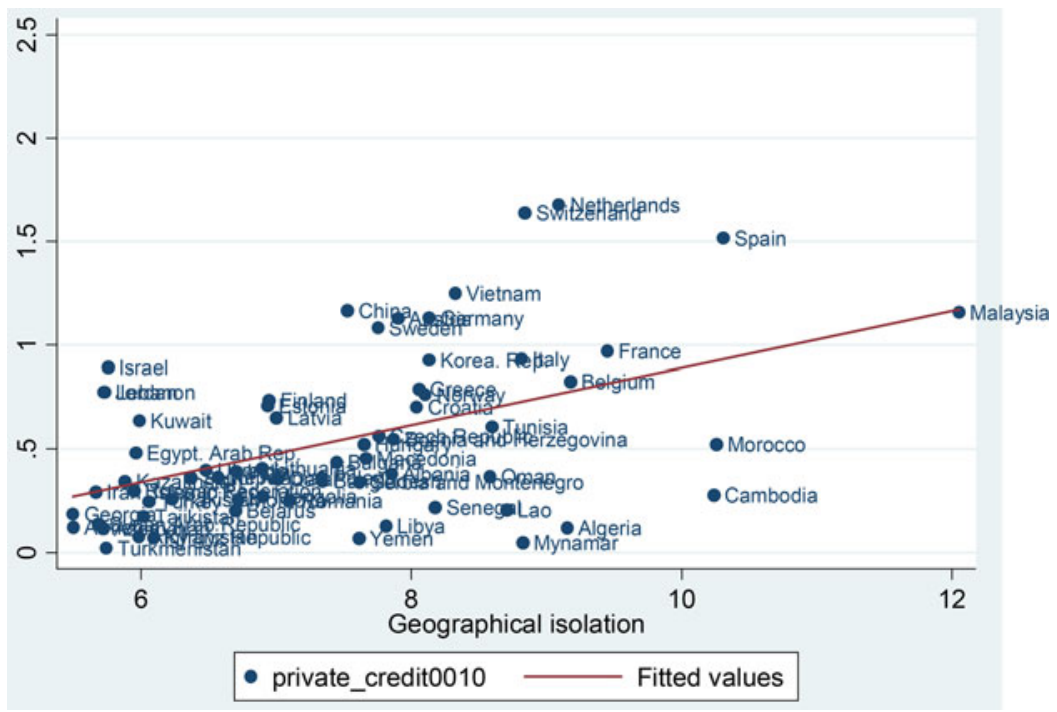

Figure I. Geographical isolation and financial development $(2000-10)^{1}$

Fischer (I998) recommended orderly openness. The perspective of Fischer (I998) is shared by Henry (2007) and Kose et al. (20 I I), with the latter perspective building on Kose et al. (2006) who have surveyed the literature and concluded that the indirect benefits are more relevant than traditional financial mechanisms articulated in previous studies. This has led to a recent stream of scholarly debates on China being de jure closed and de facto open (Prasad and Wei 2007; Aizenman and Glick 2009; Shah and Patnaik 2009). ${ }^{2}$ Moreover, according to recent literature, the gains in financial openness are increasingly blurred because financial openness is associated with, inter alia, growing external debt that is fuelling inequality (Azzimonti et al. 20 I 4) and worsening business cycles (Leung 2003) on the one hand and decreasing productivity and efficiency on the other hand (Mulwa et al. 2009).

The positioning of this inquiry steers clear of the above in that it assesses the role of geographical isolation in financial development. In other words, we examine whether prehistoric geographical isolation has been beneficial to financial development.

We examine a sample of 66 countries with average contemporary data for the period 2000-IO and prehistoric data on geographical isolation. The financial development dependent variable is private domestic credit as a percentage of GDP.

${ }^{1}$ Figure I illustrates the partial regression line for the effect of geographic isolation on financial development while controlling for other variables.

2 The de facto and de jure measures of financial globalisation are foreign direct investment and KAOPEN (from Chinn and Ito 2002) respectively. 
The independent variable of interest is the index of isolation from Ashraf et al. (2010). According to the authors, this is a new indicator of geographical isolation that was prevalent in the distant past and it represents the average time needed to travel from a country's capital to each kilometre square of land on earth, accounting for routes that can minimise the time to travel in the absence of airborne and maritime transportation technologies. The isolation index developed by the authors enables the exploitation of exogenous variation in extent of isolation, before the advent of underlying transportation technologies.

In the light of the above, for any given country, the isolation index represents the unweighted mean of the time that is needed to reach the capital of a country along paths that are cost minimising. While employing an alternative index of isolation that is limited to the average time needed to travel from the capital of one country to the capital of another does not generally change the main empirical results from a qualitative standpoint, the adopted index is better because it accounts for the potential endogeneity that arises when the locational choice associated with the development of major urban centres was not parallel to main cities' spatial distribution. Hence, the isolation index employed within the framework of this study enables the exploitation of exogenous differences in the level of isolation before the advent of airborne transportation and sea-faring. This articulation is meant to identify the effect of geographical isolation in the prehistoric era on the path of economic development via history (Ashraf et al. 2010).

Following Ang and Kumar (2014) and Kodila-Tedika and Asongu (2015b) in recent financial development literature, we control for: aerial isolation, financial openness, trade openness, interaction between financial openness and trade openness, creditors' rights, religions (Protestants, Muslims and Catholics), legal origins (French, British, Scandinavian and German), tropics and latitude. The definitions of the variables, summary statistics and correlation matrix are provided in the Appendix. We discuss the expected signs concurrently with the estimation of results.

Consistent with the above and the geographical isolation (Ashraf et al. 2010) literature, we employ Ordinary Least Squares (OLS) in order to assess the nexus between geographical isolation and financial development. The specification is presented in equation (I).

$$
F D_{i}=\alpha_{1}+\alpha_{2} G I_{i}+\alpha_{3} X_{i}+\varepsilon_{i}
$$

Where: $F D_{i}\left(G I_{i}\right)$ represents financial development (geographical isolation) indicator for country $i, \alpha_{1}$ is a constant, $X$ is the vector of control variables, and $\varepsilon$ the error term. $\mathrm{X}$ consists of: aerial isolation, trade openness, creditors' rights protection, financial openness, legal origins, tropics and latitude.

\section{III}

Table I presents findings based on regressions in equation (I). The first column which shows univariate regressions establishes a positive correlation between historical 
geographical isolation and financial development; that is, a one standard deviation increase in the average time required to walk to a country's capital from all locations in the Old World is associated with 0.48 percentage points increase in financial development and significant at I per cent. In fact, this indicates that isolation is positively correlated with private sector credit. Columns 2 to 8 examine the nexus conditional on other covariates (control variables). The ordering of the specification is in line with recent financial development literature (Ang and Kumar 20I4; Kodila-Tedika and Asongu 20I5b). The positive magnitude varies between 0.086 (column 7) and O.I 59 (column 3). The coefficient varies from 22.7 per cent in univariate regressions (column 2) to 66.2 per cent (columns 7 and 8). This consistent increasing magnitude in the adjustment coefficient is in line with the intuition because the explanatory power of a model should increase with improvements in the conditioning information set.

Most of the significant control variables have the expected signs. These include: (i) the protection of creditor rights has been documented to be linked to higher levels of financial development (La Porta et al. I998); (ii) given that financial openness is connected with availability of more external flows, it should also be linked with more possibilities for private domestic credit; (iii) countries with French legal traditions are associated with less financial development (La Porta et al. 2008; Asongu 20I2ab); (iv) compared to Muslim and Catholic nations, countries which are dominated by 'Protestants' are more likely to enjoy higher levels of financial development. The edge of the Protestant culture typically builds on Weber's (I930) 'Protestant Ethic Thesis'. According to Weber, the northern region of Europe experienced more advanced capitalism because a substantial part of the population was motivated by the Protestant ethic to set up its own enterprises. ${ }^{3}$ It is in this light that the region adopted a culture of: (i) engaging in trade and investment activities for the accumulation of wealth and (ii) working in a secular world. The 'Protestant Ethic Thesis' also elicits the negative nexus between the dependent variable and the 'Muslim dummy'. This is in accordance with the evidence that Muslim nations are less democratic (Fish 2002, p. 4).

In this section, we perform several robustness checks using the specification in column 7 of Table I as baseline. These checks include: controlling for influential observations; using alternative sample periods and varying the conditioning information set.

In order to further improve the quality of estimations, we control for influential observations following M-estimators of Huber (1973) by employing iteratively weighted least squares (IWLS). As documented by Midi and Talib (2008), compared

3 To put it more specifically, those Protestants that were followers of Calvin (the Puritans in Britain and America) were taught that prospering economically was a sign that they were members of the 'elect', destined for heaven in the next life. Thus, greed, far from being a deadly sin, was enshrined as a positive good in the culture of both Britain and America. 
Table I. OLS for the relationship between isolation and financial development

\begin{tabular}{|c|c|c|c|c|c|c|c|c|}
\hline & \multicolumn{8}{|c|}{ Dependent variable: private credit/GDP (2000-IO) } \\
\hline & I & II & III & IV & $\mathrm{V}$ & VI & VII & VIII \\
\hline Geographical isolation & $\begin{array}{l}\text { O.I } 37^{\star \star \star} \\
(0.035)\end{array}$ & $\begin{array}{l}\text { O.I } 4 \mathrm{I}^{\star \star \star} \\
(0.035)\end{array}$ & $\begin{array}{l}\text { O.I } 59^{\star \star \star} \\
(0.035)\end{array}$ & $\begin{array}{l}\text { O.II } 7^{\star \star \star} \\
(0.032)\end{array}$ & $\begin{array}{l}0.123^{\star \star \star} \\
(0.033)\end{array}$ & $\begin{array}{l}\text { O.I } 37^{\star \star \star} \\
(0.038)\end{array}$ & $\begin{array}{l}0.086^{\star \star \star} \\
(0.038)\end{array}$ & $\begin{array}{l}\text { O.I } 37^{\star \star \star} \\
(0.035)\end{array}$ \\
\hline Aerial isolation & & $\begin{array}{c}-0.017 \\
(0.038)\end{array}$ & $\begin{array}{c}-0.02 \mathrm{I} \\
(0.037)\end{array}$ & $\begin{array}{l}0.015 \\
(0.037)\end{array}$ & $\begin{array}{l}0.015 \\
(0.038)\end{array}$ & $\begin{array}{c}0.033 \\
(0.042)\end{array}$ & $\begin{array}{c}0.056 \\
(0.037)\end{array}$ & $\begin{array}{l}0.2 \mathrm{I} 3 \\
(0.037)\end{array}$ \\
\hline Creditor rights & & & $\begin{array}{l}\text { O. I I I } \\
(0.045)\end{array}$ & $\begin{array}{l}\text { O.II } 5^{\star \star \star} \\
(0.036)\end{array}$ & $\begin{array}{l}0.098^{\star \star} \\
(0.037)\end{array}$ & $\begin{array}{l}0.088^{\star \star} \\
(0.035)\end{array}$ & $\begin{array}{l}0.072^{\star \star} \\
(0.035)\end{array}$ & $\begin{array}{l}0.176^{\star \star} \\
(0.035)\end{array}$ \\
\hline Trade openness $(\mathrm{O})$ & & & & $\begin{array}{l}0.050 \\
(0.146)\end{array}$ & $\begin{array}{c}-0.059 \\
(0.145)\end{array}$ & $\begin{array}{c}-0.056 \\
(0.145)\end{array}$ & $\begin{array}{c}-0.063 \\
(0.133)\end{array}$ & $\begin{array}{c}-0.063 \\
(0.133)\end{array}$ \\
\hline Financial openness $(\mathrm{O})$ & & & & $\begin{array}{l}0.198^{\star \star \star} \\
(0.073)\end{array}$ & $\begin{array}{l}0.154^{\star} \\
(0.084)\end{array}$ & $\begin{array}{l}0.166^{\star \star} \\
(0.082)\end{array}$ & $\begin{array}{c}0.105 \\
(0.073)\end{array}$ & $\begin{array}{l}0.4 \mathrm{I} 2 \\
(0.073)\end{array}$ \\
\hline Trade $\mathrm{O} \times$ financial $\mathrm{O}$ & & & & $\begin{array}{c}-0.070 \\
(0.079)\end{array}$ & $\begin{array}{c}-0.032 \\
(0.089)\end{array}$ & $\begin{array}{c}-0.049 \\
(0.087)\end{array}$ & $\begin{array}{c}-0.027 \\
(0.077)\end{array}$ & $\begin{array}{c}-0.12 \text { I } \\
(0.077)\end{array}$ \\
\hline British legal origin & & & & & $\begin{array}{c}-0.109 \\
(0.156)\end{array}$ & $\begin{array}{c}\text { O.IOI } \\
(0.223)\end{array}$ & $\begin{array}{c}0.384 \\
(0.3 \mathrm{I} 8)\end{array}$ & $\begin{array}{c}0.305 \\
(0.3 \text { I } 8)\end{array}$ \\
\hline French legal origin & & & & & $\begin{array}{c}-0.219^{\star} \\
(0.120)\end{array}$ & $\begin{array}{c}-0.075 \\
(0.134)\end{array}$ & $\begin{array}{l}0.266 \\
(0.29 \mathrm{I})\end{array}$ & $\begin{array}{l}0.329 \\
(0.29 \mathrm{I})\end{array}$ \\
\hline German legal origin & & & & & $\begin{array}{c}-0.044 \\
\text { (0.I I } 4)\end{array}$ & $\begin{array}{c}0.036 \\
\text { (0.1 I9) }\end{array}$ & $\begin{array}{c}0.243 \\
(0.259)\end{array}$ & $\begin{array}{c}0.26 \mathrm{I} \\
(0.259)\end{array}$ \\
\hline Latitude & & & & & & $\begin{array}{c}0.436 \\
(0.3 \mathrm{I} 4)\end{array}$ & $\begin{array}{c}-0.749 \\
(0.483)\end{array}$ & $\begin{array}{c}-0.282 \\
(0.483)\end{array}$ \\
\hline Tropics & & & & & & $\begin{array}{c}-0.069 \\
(0.337)\end{array}$ & $\begin{array}{c}-0.396 \\
(0.302)\end{array}$ & $\begin{array}{c}-0.283 \\
(0.302)\end{array}$ \\
\hline Catholic fraction & & & & & & & $\begin{array}{l}0.333^{\star \star} \\
(0.147)\end{array}$ & $\begin{array}{l}0.244^{\star \star} \\
(0.147)\end{array}$ \\
\hline
\end{tabular}


Muslim fraction

Protestant fraction

\begin{tabular}{|c|c|c|c|c|c|c|c|c|}
\hline Constant & $\begin{array}{c}-0.482^{\star} \\
(0.24 \mathrm{I})\end{array}$ & $\begin{array}{c}-0.372 \\
\text { (o.344) }\end{array}$ & $\begin{array}{c}-0.689^{\star} \\
(0.365)\end{array}$ & $\begin{array}{c}-0.945^{\star \star} \\
(0.36 \mathrm{I})\end{array}$ & $\begin{array}{c}-0.677 \\
(0.4 \mathrm{I} 7)\end{array}$ & $\begin{array}{c}-\mathrm{I} .2 \mathrm{I} 2^{\star \star} \\
(0.556)\end{array}$ & $\begin{array}{c}(0.270) \\
-0.676 \\
(0.597)\end{array}$ & $(0.270)$ \\
\hline Observations & 66 & 66 & 66 & 65 & 64 & 63 & 63 & 63 \\
\hline $\mathrm{R}^{2}$ & 0.227 & $0.23 \mathrm{I}$ & 0.296 & 0.508 & 0.576 & 0.590 & 0.662 & 0.662 \\
\hline
\end{tabular}

Notes: $\star$; $\star \star ; \star \star \star$ denote significance levels of I०\%, $5 \%$ and I $\%$ respectively. 
to the approach by OLS, the IWLS technique has the advantage of simultaneously controlling for problems arising from the presence of outliers and/or heteroscedasticity. The results in Table 2 in terms of signs and significance remain consistent with those established in Table I. Moreover, the estimate corresponding to aerial isolation is now significant. Next, in column 3, we perform the sensitivity check on baseline estimates with control variables, after dropping the smallest observations. The corresponding findings are consistent with baseline results. Lastly, following Nunn and Puga (20 I 2, pp. 25-6) and Kodila-Tedika and Asongu (20 I 5b), we adopt a systematic approach of eliminating influential observations for which DFBETA $\mid>2 / \sqrt{N}$, where $\mathrm{N}$ is the number of observations. Corresponding findings in column 4 of Table 2 are consistent with baseline specifications. ${ }^{4}$

In Table 3, we employ the alternative sample periods for further robustness purposes. These include: I980-20I0; I985-20I0; I990-20I0; and I995-20IO. The resulting findings confirm the direction of the underlying correlation and further reveal that irrespective of periodicities, the link between financial development and geographical isolation is positive. Moreover, the coefficient on geographical isolation increased slightly from I980-20I0 to I995-20 IO. This incremental effect suggests that the nexus is more apparent in the contemporary era.

In Table 4, we control for other impacts to further assess the robustness of our baseline findings. We augment our baseline model with other controls such as: ethnic fragmentation; institutions; social capital; continents and income. The definitions of these variables and corresponding sources are disclosed in the Appendix. From a more general perspective, the new variables account for the unobserved heterogeneity that was not included in baseline regressions. The baseline results are confirmed in terms of significance and sign, though the correlation is lower with the addition of income, institutions and ethnic fractionalisation and higher when social capital is added. The additional control variables display anticipated signs because income levels, institutions and social capital are positively related to financial development whereas ethnic fractionalisation has the opposite effect, as demonstrated in Girma and Shortland (2008), Ang and Kumar (20I4) and Guiso et al. (2004).

We briefly document the selection of additional covariates. Guiso et al. (2004) have articulated that social capital has been instrumental in improving financial development. The positive role of institutions has also been documented by Girma and Shortland (2008). Beck et al. (2003) have demonstrated that ethnic diversity impairs financial development. Asongu (2012a) and Ang and Kumar (2014) have shown that wealthy countries are associated with higher levels of financial development.

We perform further robustness checks by using alternative financial development indicators. The scope of this extension is not limited to the financial intermediary sector (or short term finance) but is extended to stock markets (or long-term

4 'The DFBETA for a given predictor and for a specific observation is the difference between the regression coefficient calculated for all of the data and the regression coefficient calculated with that observation deleted, scaled by the standard error calculated with the observation deleted' (Seif 20 I4, p. I48). 
Table 2. Controlling for outliers

Dependent variable: private credit/GDP (2000-IO)

\begin{tabular}{lccc}
\cline { 2 - 4 } & IWLS & Omit smallest & Omit if $\mid$ DFBETA $\mid>_{2} / \sqrt{N}$ \\
\hline Geographical isolation & $0.125^{\star \star \star}$ & $0.085^{\star \star}$ & $0.103^{\star \star \star}$ \\
& $(0.032)$ & $(0.040)$ & $(0.022)$ \\
Aerial isolation & $0.054^{\star}$ & 0.054 & 0.058 \\
& $(0.032)$ & $(0.037)$ & $(0.037)$ \\
Constant & $-\mathrm{I} .276^{\star \star}$ & -0.189 & $-0.644^{\star}$ \\
& $(0.588)$ & $(0.503)$ & $(0.37 \mathrm{I})$ \\
Observations & 63 & 60 & 52 \\
$\mathrm{R}^{2}$ & 0.720 & 0.654 & 0.804 \\
\hline \hline
\end{tabular}

Notes: $\star \star \star \star ; ~ \star \star \star \star$ denote significance levels of Iо $\%, 5 \%$ and I $\%$ respectively. Control variables in the last column of Table I are included.

finance). Table 5 , Table 6 , Table 7 and Table 8 respectively show results corresponding to domestic credit, stock market capitalisation, stock-market-value traded and stock market turnover ratio. The findings are not consistent with those established earlier because financial intermediary development is more connected to geographical isolation compared to stock market development, which is more related to aerial isolation.

The findings established broadly confirm the strand of literature questioning the relevance of openness in financial intermediary development by means of allocation efficiency and international risk-sharing. As discussed in the theoretical underpinnings of the study, there is a strand of literature maintaining that openness results in global

Table 3. Estimates based on alternative sample periods

\begin{tabular}{|c|c|c|c|c|}
\hline & \multicolumn{4}{|c|}{ Dependent variable: private credit/GDP } \\
\hline & I980-20IO & I985-20IO & I990-20IO & I995-20IO \\
\hline Geographical isolation & $\begin{array}{l}0.062^{\star} \\
(0.03 \mathrm{I})\end{array}$ & $\begin{array}{l}0.065^{\star \star} \\
(0.032)\end{array}$ & $\begin{array}{l}0.075^{\star \star} \\
(0.034)\end{array}$ & $\begin{array}{l}0.08 I^{\star \star} \\
(0.037)\end{array}$ \\
\hline Aerial isolation & $\begin{array}{c}0.027 \\
(0.03 \mathrm{I})\end{array}$ & $\begin{array}{c}0.034 \\
(0.033)\end{array}$ & $\begin{array}{l}0.04 \mathrm{I} \\
(0.035)\end{array}$ & $\begin{array}{c}0.049 \\
(0.036)\end{array}$ \\
\hline Constant & $\begin{array}{c}-0.033 \\
(0.4 \mathrm{I} 2)\end{array}$ & $\begin{array}{c}-0.072 \\
(0.426)\end{array}$ & $\begin{array}{c}-0 . \mathrm{I} 4^{2} \\
(0.45 \mathrm{I})\end{array}$ & $\begin{array}{c}-0.156 \\
(0.48 \mathrm{I})\end{array}$ \\
\hline $\begin{array}{l}\text { Observations } \\
\mathrm{R}^{2}\end{array}$ & $\begin{array}{l}62 \\
0.660\end{array}$ & $\begin{array}{l}62 \\
0.674\end{array}$ & $\begin{array}{l}62 \\
0.676\end{array}$ & $\begin{array}{l}62 \\
0.670\end{array}$ \\
\hline
\end{tabular}

Notes: $\star$; $\star \star ; ~ \star \star \star$ denote significance levels of I0\%, $5 \%$ and I $\%$ respectively. Control variables in the last column of Table I are included. 
Table 4. Controlling for other effects

\begin{tabular}{|c|c|c|c|c|c|c|}
\hline & \multicolumn{6}{|c|}{ Dependent variable: private credit/GDP (2000-20I0) } \\
\hline & $\begin{array}{c}\text { Add ethnic } \\
\text { fractionalisation }\end{array}$ & $\begin{array}{c}\text { Add } \\
\text { institutions }\end{array}$ & $\begin{array}{l}\text { Add social } \\
\text { capital }\end{array}$ & $\begin{array}{c}\text { Add } \\
\text { continents }\end{array}$ & $\begin{array}{l}\text { Add } \\
\text { income }\end{array}$ & $\begin{array}{c}\text { Add all other } \\
\text { effects }\end{array}$ \\
\hline Geographical isolation & $\begin{array}{l}0.075^{\star} \\
(0.039)\end{array}$ & $\begin{array}{c}0.060^{\star} \\
(0.033)\end{array}$ & $\begin{array}{l}0.085^{\star \star} \\
(0.040)\end{array}$ & $\begin{array}{c}0.069 \\
(0.05 \mathrm{I})\end{array}$ & $\begin{array}{c}0.067 \\
(0.04 \mathrm{I})\end{array}$ & $\begin{array}{l}0.097^{\star \star} \\
(0.045)\end{array}$ \\
\hline Aerial isolation & $\begin{array}{c}0.05 \mathrm{I} \\
(0.035)\end{array}$ & $\begin{array}{l}0.058^{\star} \\
(0.032)\end{array}$ & $\begin{array}{c}0.05 \mathrm{I} \\
(0.034)\end{array}$ & $\begin{array}{l}0.076 \\
(0.054)\end{array}$ & $\begin{array}{l}0.060 \\
(0.037)\end{array}$ & $\begin{array}{c}0.04 \mathrm{I} \\
(0.06 \mathrm{I})\end{array}$ \\
\hline $\begin{array}{l}\text { Ethnic } \\
\text { fractionalisation }\end{array}$ & $\begin{array}{r}-0.330^{\star} \\
(0.167)\end{array}$ & & & & & $\begin{array}{l}0.037 \\
(0.226)\end{array}$ \\
\hline Institutions & & $\begin{array}{l}0.059^{\star \star \star} \\
(0.020)\end{array}$ & & & & $\begin{array}{l}0.052^{\star \star} \\
(0.025)\end{array}$ \\
\hline Social capital & & & $\begin{array}{l}0.825^{\star \star} \\
(0.377)\end{array}$ & & & $\begin{array}{l}0.917^{\star \star} \\
(0.402)\end{array}$ \\
\hline Europe & & & & $\begin{array}{c}0.07 \mathrm{I} \\
(0.205)\end{array}$ & & $\begin{array}{c}0.132 \\
(0.233)\end{array}$ \\
\hline Asia & & & & $\begin{array}{r}-0.040 \\
(0.165)\end{array}$ & & $\begin{array}{l}\text { O.I } 88 \\
(0.232)\end{array}$ \\
\hline lGDP & & & & & $\begin{array}{c}0.08 I^{\star} \\
(0.044)\end{array}$ & $\begin{array}{c}0.025 \\
(0.066)\end{array}$ \\
\hline Constant & $\begin{array}{c}0.079 \\
(0.533)\end{array}$ & $\begin{array}{r}-0.750 \\
(0.589)\end{array}$ & $\begin{array}{l}-0.625 \\
(0.612)\end{array}$ & $\begin{array}{r}-0.624 \\
(0.6 \mathrm{IO})\end{array}$ & $\begin{array}{l}-\mathrm{I} .3 \mathrm{I} 6^{\star \star} \\
(0.56 \mathrm{I})\end{array}$ & $\begin{array}{r}-\mathrm{I} .258 \\
(0.743)\end{array}$ \\
\hline Observations & 62 & 63 & 49 & 63 & 63 & 49 \\
\hline $\mathrm{R}^{2}$ & 0.685 & 0.715 & 0.790 & 0.664 & 0.682 & 0.838 \\
\hline
\end{tabular}

Notes: $\star$; $\star \star ; \star \star \star$ denote significance levels of $\mathrm{I} \% \%, 5 \%$ and I $\%$ respectively. Control variables in the last column of Table I are included. 
Table 5. Using domestic credit as a measure of financial development

\begin{tabular}{|c|c|c|c|c|c|}
\hline & \multicolumn{5}{|c|}{ Dependent variable: domestic Credit/GDP (2000-Io) } \\
\hline & I & II & III & IV & $\mathrm{V}$ \\
\hline Geographical isolation & $\begin{array}{l}0.070 \\
(0.05 \mathrm{I})\end{array}$ & $\begin{array}{l}0.106 \star \star \\
(0.050)\end{array}$ & $\begin{array}{l}0.039 \\
(0.046)\end{array}$ & $\begin{array}{l}0.055 \\
(0.053)\end{array}$ & $\begin{array}{c}0.061 \\
(0.052)\end{array}$ \\
\hline Aerial isolation & $\begin{array}{c}0.062 \\
(0.047)\end{array}$ & $\begin{array}{c}0.06 \mathrm{I} \\
(0.042)\end{array}$ & $\begin{array}{c}0.064 \\
(0.059)\end{array}$ & $\begin{array}{c}0.053 \\
(0.042)\end{array}$ & $\begin{array}{c}0.062 \\
(0.046)\end{array}$ \\
\hline Social capital & & $\begin{array}{l}0.628 \\
(0.494)\end{array}$ & & & \\
\hline Institutions & & & $\begin{array}{l}0.07 \mathrm{I}^{\star x} \\
(0.027)\end{array}$ & & \\
\hline Ethnic fractionalisation & & & & $\begin{array}{l}-0.544^{\star \star} \\
(0.252)\end{array}$ & \\
\hline lGDP & & & & & $\begin{array}{c}0.054 \\
(0.059)\end{array}$ \\
\hline Constant & $\begin{array}{l}-0.502 \\
(0.755)\end{array}$ & $\begin{array}{r}-0.38 \mathrm{I} \\
(0.662)\end{array}$ & $\begin{array}{l}-0.59 \mathrm{I} \\
(0.680)\end{array}$ & $\begin{array}{l}0.523 \\
(0.693)\end{array}$ & $\begin{array}{r}-0.930 \\
(0.856)\end{array}$ \\
\hline $\begin{array}{l}\text { Number of observations } \\
\mathrm{R}^{2}\end{array}$ & $\begin{array}{l}63 \\
0.602\end{array}$ & $\begin{array}{l}49 \\
0.733\end{array}$ & $\begin{array}{l}63 \\
0.659\end{array}$ & $\begin{array}{l}62 \\
0.647\end{array}$ & $\begin{array}{l}63 \\
0.608\end{array}$ \\
\hline
\end{tabular}

Notes: $\star ; \star \star ; \star \star \star \star$ denote significance levels of I0\%, $5 \%$ and I $\%$ respectively. Control variables in the last column of Table I are included.

financial instability (Stiglitz 2000; Rodrik I998; Bhagwati I998), while another strand maintains that growing financial integration has improved economic stability in developed countries while enabling low-income countries to make the transition to middle-income countries (Fischer 1998; Summers 2000).

The findings can also be viewed to be in accordance with recent development literature that holds that openness has not resulted in more investment in developing countries and stability in developed countries (see Rodrik and Subramanian 2009). This is essentially because, according to the narrative, countries that have enjoyed more economic development in recent decades have surprisingly been those that have been least opened. For instance, Asongu (2014) has argued that contemporary evidence for the development rewards from openness remain unpersuasive, indirect and speculative. Moreover, the findings also support the view that more resources from economic openness are not necessarily better.

As long as the world economy remains politically divided among different sovereign and regulatory authorities, global finance is condemned to suffer from deformation far worse than those of domestic finance. Depending on the context and country, the appropriate role of policy will be as often to stem the tide of capital flows as to encourage them. Policymakers who view their challenges exclusively from the latter perspective will get it badly wrong. (Rodrik and Subramanian 2009, pp. I6-I7) 
Table 6. Using stock market capitalisation as a measure of financial development

\begin{tabular}{|c|c|c|c|c|c|}
\hline & \multicolumn{5}{|c|}{$\begin{array}{l}\text { Dependent variable: stock market capitalisation/GDP } \\
\qquad(2000-\mathrm{IO})\end{array}$} \\
\hline & I & II & III & IV & V \\
\hline Geographical isolation & $\begin{array}{c}0.034 \\
(0.060)\end{array}$ & $\begin{array}{l}\text { O.OI I } \\
(0.065)\end{array}$ & $\begin{array}{l}0.03 \mathrm{I} \\
(0.062)\end{array}$ & $\begin{array}{l}0.0 \mathrm{II} \\
(0.070)\end{array}$ & $\begin{array}{l}0.025 \\
(0.06 \mathrm{I})\end{array}$ \\
\hline Aerial isolation & $\begin{array}{c}0.048 \\
(0.049)\end{array}$ & $\begin{array}{l}0.053 \\
(0.036)\end{array}$ & $\begin{array}{c}0.048 \\
(0.049)\end{array}$ & $\begin{array}{c}0.058 \\
(0.053)\end{array}$ & $\begin{array}{l}0.082 \\
(0.069)\end{array}$ \\
\hline 1GDP & & $\begin{array}{l}0.156^{\star \star} \\
(0.067)\end{array}$ & & & \\
\hline Ethnic fractionalisation & & & $\begin{array}{c}-0.08 \mathrm{I} \\
(0.252)\end{array}$ & & \\
\hline Institutions & & & & $\begin{array}{l}0.042 \\
(0.037)\end{array}$ & \\
\hline Social capital & & & & & $\begin{array}{l}0.353 \\
(0.45 \mathrm{I})\end{array}$ \\
\hline Constant & $\begin{array}{r}-0.070 \\
(0.868)\end{array}$ & $\begin{array}{r}-\mathrm{I} .436 \\
(\mathrm{I} .056)\end{array}$ & $\begin{array}{r}-0.046 \\
(0.870)\end{array}$ & $\begin{array}{r}-0.178 \\
(0.830)\end{array}$ & $\begin{array}{r}-0.385 \\
(0.868)\end{array}$ \\
\hline Number of observations & $5 \mathrm{I}$ & $5 \mathrm{I}$ & 5I & $5 \mathrm{I}$ & 43 \\
\hline $\mathrm{R}^{2}$ & 0.675 & 0.723 & 0.676 & 0.688 & $0.72 \mathrm{I}$ \\
\hline
\end{tabular}

Notes: $\star \star \star \star ; ~ \star \star \star \star$ denote significance levels of $\mathrm{I} \% \%, 5 \%$ and I $\%$ respectively. Control variables in the last column of Table I are included.

There is a recent strand of literature documenting evidence that prehistoric geographical isolation had a fundamental cultural impact on the development process that has contributed to contemporary variations in economic development. This study has expanded this strand of literature by assessing whether prehistoric geographical isolation is related to development outcomes such as financial development. We have exploited prehistoric cross-country differences in geographical isolation in order to assess its effect on financial development across the globe. Prehistoric geographical isolation is defined as prior to the advent of airborne and sea-faring technologies of transportation. We find that prehistoric geographical isolation has been beneficial to development because it has contributed to contemporary cross-country differences in financial intermediary development. The relationship is robust to alternative samples, different estimation techniques, outliers and varying conditioning information sets. The findings broadly confirm the positive relationship between geographical isolation and GDP per capita established by Ashraf et al. (20I0). Unfortunately, the established positive relationship between geographical isolation and financial intermediary development does not significantly extend to stock market development. 
Table 7. Using stock market value traded as a measure of financial development

\begin{tabular}{|c|c|c|c|c|c|}
\hline & \multicolumn{5}{|c|}{ Dependent variable: stock market value traded/GDP (2000-I0) } \\
\hline & I & II & III & IV & $\mathrm{V}$ \\
\hline Geographical isolation & $\begin{array}{c}0.073 \\
(0.057)\end{array}$ & $\begin{array}{c}0.055 \\
(0.057)\end{array}$ & $\begin{array}{c}0.062 \\
(0.06 \mathrm{I})\end{array}$ & $\begin{array}{c}0.040 \\
(0.059)\end{array}$ & $\begin{array}{l}0.045 \\
(0.055)\end{array}$ \\
\hline Aerial isolation & $\begin{array}{l}\text { O.I } 28^{\star \star} \\
(0.059)\end{array}$ & $\begin{array}{l}0.136^{\star \star \star} \\
(0.048)\end{array}$ & $\begin{array}{l}\text { O.I3 I } \\
(0.058)\end{array}$ & $\begin{array}{l}\text { O.I } 42^{\star \star} \\
(0.064)\end{array}$ & $\begin{array}{l}\text { O.I64 } \\
(0.088)\end{array}$ \\
\hline 1GDP & & $\begin{array}{l}\text { O.I35 } \\
\text { (0.099) }\end{array}$ & & & \\
\hline Ethnic fractionalisation & & & $\begin{array}{c}-0.396 \\
(0.383)\end{array}$ & & \\
\hline Institutions & & & & $\begin{array}{c}0.059 \\
(0.04 \mathrm{I})\end{array}$ & \\
\hline Social capital & & & & & $\begin{array}{c}0.765 \\
(0.74 \mathrm{I})\end{array}$ \\
\hline Constant & $\begin{array}{c}-\mathrm{I} .033 \\
(0.907)\end{array}$ & $\begin{array}{c}-2.353^{\star} \\
(1.360)\end{array}$ & $\begin{array}{c}- \text { I.OI I } \\
(0.898)\end{array}$ & $\begin{array}{r}-\mathrm{I} .204 \\
(\mathrm{o} .889)\end{array}$ & $\begin{array}{r}-\mathrm{I} . \mathrm{I} 4 \mathrm{O} \\
(0.908)\end{array}$ \\
\hline Number of observations & $5 \mathrm{I}$ & $5 \mathrm{I}$ & $5 \mathrm{I}$ & $5 \mathrm{I}$ & 43 \\
\hline $\mathrm{R}^{2}$ & $0.64 \mathrm{I}$ & 0.669 & 0.658 & 0.663 & $0.76 \mathrm{I}$ \\
\hline
\end{tabular}

Notes: $\star ; \star \star ; \star \star \star \star$ denote significance levels of I0\%, $5 \%$ and I $\%$ respectively. Control variables in the last column of Table I are included.

Ashraf et al. (20 IO) and Özak (20I6) have shown that isolation may affect development through various cultural or institutional channels; one such channel may thus be financial development as established in this study, given the consensus on the positive relationship between financial development and economic development (Nyasha and Odhiambo 2015a, 20 I 5b). Notwithstanding, financial development is the final result of development. Under this scenario, it implies that the hegemonic and neoliberal arguments may be used to justify the need for isolation in view of increasing financial development. These arguments also double as channels that may dissuade openness or motivate isolation. We discuss these arguments in detail below.

First, hegemonic deterrence to openness which has been clarified in Section I maintains that governments may be averse to opening up their economies because openness, especially in the perspective of globalisation, is viewed as a hidden attempt by the more powerful nations and corporations to control the less powerful. This view is well articulated in a study on recent advances in finance for inclusive development by Asongu and Nwachukwu (2017), a study which has been motivated by the hegemonic perspective. Accordingly, the following facts are for the most part traceable to growing openness. World Hunger (20IO) has maintained that the principal cause of hunger and poverty in the contemporary world is a globalised economic system which encourages a very tiny minority to own a vast majority of global wealth, 
Table 8. Using stock market turnover ratio as a measure of financial development

\begin{tabular}{|c|c|c|c|c|c|}
\hline & \multicolumn{5}{|c|}{$\begin{array}{l}\text { Dependent variable: stock market turnover ratio/GDP } \\
\qquad(2000-10)\end{array}$} \\
\hline & I & II & III & IV & V \\
\hline Geographical isolation & $\begin{array}{l}\text { O.II7 } \\
\text { (0.IO8) }\end{array}$ & $\begin{array}{l}\text { O.IO8 } \\
\text { (O.III) }\end{array}$ & $\begin{array}{l}\text { O.IIO } \\
\text { (O.III })\end{array}$ & $\begin{array}{l}0.087 \\
(0.120)\end{array}$ & $\begin{array}{l}0.028 \\
(0.1 \mathrm{I} 2)\end{array}$ \\
\hline Aerial isolation & $\begin{array}{l}0.234^{\star \star} \\
(0.109)\end{array}$ & $\begin{array}{l}0.236^{\star \star} \\
(0.107)\end{array}$ & $\begin{array}{l}0.235^{\star \star} \\
\text { (O.III) }\end{array}$ & $\begin{array}{l}0.247^{\star \star} \\
(0.117)\end{array}$ & $\begin{array}{l}0.389^{\star \star \star} \\
(0.103)\end{array}$ \\
\hline 1GDP & & $\begin{array}{l}0.057 \\
(0.17 \mathrm{I})\end{array}$ & & & \\
\hline Ethnic fractionalisation & & & $\begin{array}{l}-0.218 \\
(0.520)\end{array}$ & & \\
\hline Institutions & & & & $\begin{array}{l}0.053 \\
(0.07 \mathrm{I})\end{array}$ & \\
\hline Social capital & & & & & $\begin{array}{c}-\mathrm{I} .033 \\
(0.893)\end{array}$ \\
\hline Constant & $\begin{array}{c}-2.746^{\star} \\
(1.367)\end{array}$ & $\begin{array}{c}-3.249^{\star} \\
(1.630)\end{array}$ & $\begin{array}{c}-2.68 \mathrm{I}^{\star} \\
(\mathrm{I} .432)\end{array}$ & $\begin{array}{c}-2.884^{\star \star} \\
(\mathrm{I} .360)\end{array}$ & $\begin{array}{r}-\mathrm{I} .878 \\
(\mathrm{I} .263)\end{array}$ \\
\hline Number of observations & $5 \mathrm{I}$ & $5 \mathrm{I}$ & $5 \mathrm{I}$ & $5 \mathrm{I}$ & 43 \\
\hline $\mathrm{R}^{2}$ & 0.399 & 0.402 & 0.402 & $0.4 \mathrm{IO}$ & 0.558 \\
\hline
\end{tabular}

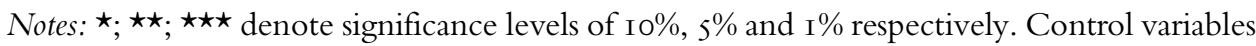
in the last column of Table I are included.

whereas the rest of the world is just left to survive. Global inequality has been rising over the past decades (Freeman 20IO; Milanovic 2OII) and according to Joseph Stiglitz: 'There has been no improvement in well-being for the typical American family for 20 years. On the other side, the top one percent of the population gets 40 per cent more in one week than the bottom fifth receive in a full year' (Nabi $203_{3}$, p.IO). Some narratives posit that only the top I per cent have benefited from the recent economic recovery (Cover 2015). While in 2015 the income of the top I per cent was estimated to exceed that of the bottom 99 percent by 2016 (Oxfam 20I5), in 2017 eight men in the world owned the same wealth as half of the world's population or 3.6 billion people (Oxfam 20I7).

Second, the neoliberal deterrent to openness may build on the evidence that openness has been detrimental to financial development owing of the intensity and magnitude of global crisis. This position can be summarised by Buckle (2009): 'The modern era of globalisation has been associated with significant economic transformation around the world, but also an increasing frequency of financial crises. According to Eichengreen and Bordo (2002) there were 39 national or international financial crises between I945 and I973. Their frequency increased to I 39 between I973 and 
I997, culminating in the Asian financial crisis. These crises occurred predominantly, but not exclusively, in emerging economies' (Buckle 2009, p. 36).

Future studies can improve the extant knowledge by assessing whether established linkages withstand further empirical validity when 'contemporary development' is replaced with 'historic development' as an outcome variable. Moreover, assessing the relationship between isolation and other macroeconomic outcomes is also an interesting future research direction. The main caveat of the study is that the findings can be interpreted exclusively as relationships, not causality. Hence, as more data become available, it will be interesting to assess whether the established linkages hold from the perspective of causality.

Submitted: 29 March 2017

Revised version submitted: Io August 2017

Accepted: 28 September 2017

First published online: I8 December 2017

\section{References}

AGHION, P. and BOLTON, P. (1992). An incomplete contracts approach to financial contracting. Review of Economic Studies, 59(3), pp. 473-94.

AIZENMAN, J. and GLICK, R. (2009). Sterilization, monetary policy, and global financial integration. Review of International Economics, I7(4), pp. 777-80I.

ALESINA, A., DEVLEESCHAUWER, A., EASTERLY, W., KURLAT, S. and WACZIARG, R. (2003). Fractionalization. Journal of Economic Growth, 8(2), pp. I 55-94.

ANG, J. B. (20I3). Are modern financial systems shaped by state antiquity? Journal of Banking and Finance, 37(II), pp. 4038-58.

ANG, J. B. and KUMAR, S. (2OI4). Financial development and barriers to the cross-border diffusion of financial innovation. Journal of Banking and Finance, 39(February), pp. 43-56.

ASHRAF, Q., ÖZAK, O. and GALOR, O. (20I0). Isolation and development. Journal of the European Economic Association, 8(2-3), pp. 4OI-I2.

ASONGU, S. A. (20I2a). Government quality determinant of stock market performance in African countries. Journal of African Business, I3(3), pp. I 83-99.

ASONGU, S. A. (20I2b). Law and finance in Africa. Brussels Economic Review, 55(4), pp. 385-408.

ASONGU, S. A. (20I3). Globalization and Africa: implications for human development. International Journal of Development Issues, I2(3), pp. 21 3-38.

ASONGU, S. A. (2OI4). Financial development dynamic thresholds of financial globalisation: evidence from Africa. Journal of Economics Studies, 4I(2), pp. I66-95.

ASONGU, S. A. and DE MOOR, L. (20I7). Financial globalisation dynamic thresholds for financial development: evidence from Africa. European Journal of Development Research, 29(I), pp. I92-2I2.

ASONGU, S. A. and NWACHUKWU, J. C. (2017). Recent finance advances in information technology for inclusive development: a survey. African Governance and Development Institute Working Paper no. I7/oog, Yaoundé.

AZZIMONTI, M., DE FRANCISCO, E. and QUADRINI, V. (20I4). Financial globalisation, inequality and the rising public debt. American Economic Review, I04(8), pp. 2267-302.

BALTAGI, B. H., DEMETRIADES, P. and LAW, S. H. (2009). Financial development and openness: evidence from panel data. Journal of Development Economics, 89(2), pp. $285-96$.

BATUO, M. E. and ASONGU, S. A. (2OI 5 ). The impact of liberalisation policies on income inequality in African countries. Journal of Economic Studies, $\mathbf{4 2}(\mathrm{I})$, pp. 68-Io0.

BECERRA, O., CAVALlO, E. A. and SCARTASCINI, C. (20I2). The politics of financial development: the role of interest groups and government capabilities. Journal of Banking and Finance, 36(3), pp. 626-43. 
BECK, T., DEMIRGÜÇ-KUNT, A. and LEVINE, R. (2003). Law, endowments, and finance. Journal of Financial Economics, 70(2), pp. I 37-8I.

BECK, T., DEMIRGÜÇ-KUNT, A. and LEVINE, R. (20I0). Financial institutions and markets across countries and over time: the updated financial development and structure database. World Bank Economic Review, 24(I), pp. 77-92.

BHAGWATI, J. (I998). The capital myth. the difference between trade in widgets and dollars. Foreign Affairs, 7(3), pp. 7-I2.

BJØRNSKOV, C. (2008). Social trust and fractionalization: a possible reinterpretation. European Sociological Review, 24(3), pp. 27I-83.

BUCKLE, B. (2009). Asia-Pacific growth: before and after the global financial crisis. Policy Quarterly, 5(4), pp. $36-45$.

CHINN, M. D. and ITO, H. (2002). Capital account liberalization, institutions and financial development: cross country evidence. NBER Working Paper no. 8967.

COCCORESE, P. (2012). Information sharing, market competition and antitrust intervention: a lesson from the Italian insurance sector. Applied Economics, 44(3), pp. $35 \mathrm{I}-9$.

COCCORESE, P. and PELLECCHIA, A. (20I0). Testing the 'quiet life' hypothesis in the Italian banking industry. Economic Notes by Banca dei Paschi di Siena SpA, 39(3), pp. I73-202.

COVERT, B. (20I5). The I percent have gotten all the income gains from the recovery. Think Progress. http:// thinkprogress.org/economy/20I5/OI/28/36I6308/income-inequality-2013/ (accessed 04/02/2015).

DJANKOV, S., MCLIESH, C. and SHLEIFER, A. (2007). Private credit in I29 countries. Journal of Financial Economics, 84(2), pp. 299-329.

DORNBUSCH, R. (1996). It's time for a financial transactions tax. International Economy, August/ September.

DORNBUSCH, R. (1998). Capital controls: an idea whose time is past. In S. Fischer et al., Should the IMF Pursue Capital-Account Convertibility? Essays in International Finance no. 207. Princeton, NJ: International Finance Section, Princeton University.

EFOBI, E. R., OSABUOHIEN, E. S. and STEPHEN, O. (2015). One dollar, one bank account: remittance and bank breadth in Nigeria. Journal of International Migration and Integration, I6(3), pp. $76 \mathrm{I}-8 \mathrm{I}$.

EICHENGREEN, B. and BORDO, M. D. (2002). Crises now and then: what lessons from the last era of financial globalization? NBER Working Paper no. 87i6.

FISCHER, S. (I998). Capital account liberalization and the role of the IMF. In S. Fischer et al., Should the IMF Pursue Capital-Account Convertibility? Essays in International Finance no. 207. Princeton, NJ: International Finance Section, Princeton University.

FISH, S. M. (2002). The new era in world politics after September I I: Islam and authoritarianism. World Politics, 55(I), pp. 4-37.

FREEMAN, R. B. (20 Io). It's financialization. International Labour Review, I49(2), pp. I63-83.

GALLUP, J. L., SACHS, J. D. and MELLINGER, A. (I999). Geography and economic development. Center for International Development (Harvard University), Working Papers no. I.

GIRMA, S. and SHORTLAND, A. (2008). The political economy of financial development. Oxford Economic Papers, 60(4), pp. 567-96.

GRENNES, T. (2003). Creative destruction and globalization. Cato Journal, 22(3), pp. 543-58.

GUISO, L., SAPIENZA, P. and ZINGALES, L. (2004). The role of social capital in financial development. American Economic Review, 94(3), pp. 526-56.

HENRY, P. B. (2007). Capital account liberalization: theory, evidence and speculation. Journal of Economic Literature, 45, pp. 887-935.

HUBER, P. J. (1973). Robust regression: asymptotics, conjectures and Monte Carlo. The Annals of Statistics, I(s), pp. 799-82 I.

KAUFMANN, D., KRAAY, A. and MASTRUZZI, M. (2010). The worldwide governance indicators: methodology and analytical issues. Policy Research Working Paper Series 5430, The World Bank, Washington, DC.

KAYIZZI-MUGERWA, S. (200I). Globalisation, growth and income inequality: the African experience. Working Paper no. I 86, OECD Development Centre, Paris.

KODILA-TEDIKA, O. and ASONGU, S. A. (2015a). Tribalism and financial development. African Governance and Development Institute Working Paper no. i 5/o I 8, Yaoundé. 
KODILA-TEDIKA, O. and ASONGU, S. A. (20I5b). The effect of intelligence on financial development: a cross-country comparison. Intelligence, 5I(July-August), pp. I-9.

KOSE, M. A., PRASAD, E. S., ROGOFF, K. and WEI, S. J. (2006). Financial globalization: a reappraisal. IMF Staff Papers, 56(I), pp. 8-62.

KOSE, M. A., PRASAD, E. S. and TAYLOR, A. D. (2OI I). Threshold in the process of international financial integration. Journal of International Money and Finance, 30(I), pp. I47-79.

LANE, P. R. and MILESI-FERRETTI, G. M. (2007). The external wealth of nations market: revised and extended estimates of foreign assets and liabilities, I970-2004. Journal of International Economics, 73(2), pp. 223-50.

LA PORTA, R., FLORENCIO, L.-D.-S., SHLEIFER, A. and VISHNY, R.W. (I997). Legal determinants of external finance. Journal of Finance, 52(3), pp. I I 3 I-5O.

LA PORTA, R., FLORENCIO, L.-D.-S., SHLEIFER, A. and VISHNY, R.W. (I998). Law and finance. Journal of Political Economy, Io6(6), pp. I I I3-55.

LA PORTA, R., LOPEZ-DE-SILANES, F. and SHLEIFER, A. (2008). The economic consequences of legal origins. Journal of Economic Literature, 46(2), pp. 28 5-332.

LA PORTA, R., LOPEZ-DE-SILANES, F., SHLEIFER, A. and VISHNY, R. (I999). The quality of government. Journal of Law, Economics and Organization, I5(I), pp. 222-79.

LEUNG, H. M. (2003). External debt and worsening business cycles in less developed countries. Journal of Economic Studies, 30(2), pp. I55-68.

MIDI, H. and TALIB, B. A. (2008). The performance of robust estimator on linear regression model having both continuous and categorical variables with heteroscedastic errors. Malaysian Journal of Mathematical Sciences, 2(I), 25-48.

MILANOVIC, B. (20I I). More or less? Finance \& Development, 48(3). www.imf.org/external/pubs/ft/ fandd/20II/09/Milanovic.htm (accessed 4 February 20I5).

MOTELLE, S. and BIEKPE, N. (2OI5). Financial integration and stability in the Southern African development community. Journal of Economics and Business, 79(May-June), pp. Ioo-I7.

MULWA, M. R., EMROUZNEJAD, A. and MURITHI, F. M. (2009). Impact of liberalization on efficiency and productivity of sugar industry in Kenya. Journal of Economic Studies, 36(3), pp. 250-64.

MUSILA, J. W. and SIGUÉ, S. P. (20 I0). Corruption and international trade: an empirical investigation of African countries. World Economy, 33(I), pp. I29-46.

NABI, M. S. (20I3). Role of Islamic finance in promoting inclusive economic development. Paper presented at the Global Sustainable Finance Conference 20I3, Germany, 4-5 July 2013. www. wfdfi.net/wp-content/uploads/20I3/o9/6-Mahmud_Nabi.pdf (accessed 4 February 2015).

NYASHA, S. and ODHIAMBO, N. M. (2OI $5 \mathrm{a})$. Do banks and stock market spur economic growth? Kenya's experience. International Journal of Sustainable Economy, 7(I), pp. 54-65.

NYASHA, S. and ODHIAMBO, N. M. (2OI 5 b). The impact of banks and stock market development on economic growth in South Africa: an ARDL-bounds testing approach. Contemporary Economics, 9(I), pp. 93-IO8.

NUNN, N. and PUGA, G. (2012). Ruggedness: the blessing of bad geography in Africa. Review of Economics and Statistics, 94(4), pp. 20-36.

OBENG-ODOOM, F. (20I3). Africa's failed economic development trajectory: a critique. African Review of Economics and Finance, 4(2), pp. I 5 I-75.

OBENG-ODOOM, F. (2015). Africa: on the rise, but to where? Forum for Social Economics, 44(3), pp. 234-50.

OBSTFELD, M. (I998). The global capital market: benefactor or menace? Journal of Economic Perspectives, I2(4), pp. 9-30.

OSABUOHIEN, E. S. and EFOBI, E. R. (2013). Africa's money in Africa. South African Journal of Economics, 8I(2), pp. 292-306.

OXFAM (20I5). Richest I\% will own more than all the rest by 20I6. Oxfam International. www.oxfam. $\mathrm{org} / \mathrm{en} / \mathrm{pressroom} / \mathrm{pressreleases} / 20 \mathrm{I}$ 5-OI-I9/richest-I-will-own-more-all-rest-20I6 (accessed 4 February 2015).

OXFAM (2017). Just 8 men own same wealth as half the world. Oxfam International. www.oxfam.org/ en/pressroom/pressreleases/20I7-OI-I6/just-8-men-own-same-wealth-half-world (accessed 25 February 2017). 
ÖZAK, O. (20I6). Distance to the pre-industrial technlogical frontier and economic development. MPRA Paper no. 74737, Munich.

PETRAS, J. and VELTMEYER, H. (200I). Globalization Unmasked: Imperialism in the 21st Century. London: Zed Books.

PRASAD, E. S. and WEI., S. J. (2007). China's approach to capital inflows: patterns and possible explanations. In S. Edwards (ed.), Capital Controls and Capital Flows in Emerging Economies: Policies, Practices, and Consequences. Chicago: University of Chicago Press.

PRICE, G. N. and ELU, J. U. (2OI4). Does regional currency integration ameliorate macroeconomic shocks in sub-Saharan Africa? The case of the 2008-2009 global financial crisis. Journal of Economic Studies, 4I(5), pp. 737-50.

RAJAN, R. G. and ZINGALES, L. (1998). Financial dependence and growth. American Economic Review, 88(3), pp. 559-86.

RODRIK, D. (1998). Who needs capital-account convertibility? In S. Fischer et al., Should the IMF Pursue Capital-Account Convertibility? Essays in International Finance no. 207. Princeton, NJ: International Finance Section, Princeton University.

RODRIK, D. and SUBRAMANIAN, A. (2009). Why did financial globalization disappoint? IMF Staff Papers, 56(I), pp. I I2-38.

ROGOFF, K. S. (I999). International institutions for reducing global financial instability. Journal of Economic Perspectives, $\mathbf{I 3}(4)$, pp. $2 \mathrm{I}-42$.

SCHOLTE, J. A. (2000). Globalisation: A Critical Introduction. New York: St Martin's Press.

SEIF, R. (20I4). Statistical Analysis of Matching Processes of Composite Materials. University of Montreal. http://publications.polymtl.ca/I606/I/20I4_RandaSeif.pdf (accessed 24 April 20I5).

SHAH, A. and PATNAIK, I. (2009). Asia confronts the impossible trinity. Mimeo, NIPFPDEA.

SIRGY, M. J., LEE, D. J., MILLER, C. and LITTLEFIELD, J. E. (2004). The impact of globalization on a country's quality of life: toward an integrated model. Social Indictors Research, 68(3), pp. 25 I-98.

SMART, B. (2003). Economy, Culture and Society: A Sociological Critique of Neo-liberalism. Buckingham: Open University Press.

STIGLITZ, J. E. and WEISS, A. (I98I). Credit rationing in markets with imperfect information. American Economic Review, 7I(3), pp. 393-4Iо.

SOLOW, R. M. (I956). A contribution to the theory of economic growth. Quarterly Journal of Economics, 70(I), pp. 65-94.

STIGLITZ, J. (2000). Capital market liberalization, economic growth and instability. World Development, 28(6), pp. I075-86.

STULZ, R. M. and WILLIAMSON, R. (2003). Culture, openness, and finance. Journal of Financial Economics, 7o(3), pp. 3I $3-49$.

SUMMERS, L. H. (2000). International financial crises: causes, prevention and cures. American Economic Review, 90(2), pp. I-I6.

TCHAMYOU, V. S. (2016). The role of knowledge economy in African business. Journal of the Knowledge Economy. DOI: I0.1007/sI3I32-0I6-04I7-I.

TCHAMYOU, V. S. and ASONGU, S. A. (2017). Information sharing and financial sector development in Africa. Journal of African Business, I8(I) pp. 24-49.

TSAI, M. (2006). Does globalisation affect human well-being? Unpublished paper, Department of Sociology, National Taipei University, Taiwan.

WEBER, M. (1930). The Protestant Ethic and The Spirit of Capitalism, trans. P. Baehr and G. C. Wells. London: Penguin.

WORLD HUNGER (20I0). The major barrier to people's welfare and development. Hunger Notes. http://worldhunger.org/harmfuleconomicsystems.htm (accessed 4 February 2015). 
Appendix: Data sources and summary statistics of variables

Table Aı. Definitions and sources of variables

\begin{tabular}{|c|c|c|}
\hline Variables & Definitions & Sources \\
\hline \multirow[t]{2}{*}{ Private credit } & $\begin{array}{l}\text { Value of financial intermediaries' credits to } \\
\text { the private sector as a share of GDP } \\
\text { (excludes credit to the public sector and } \\
\text { credit issued by central and development } \\
\text { banks), average over 2000-IO }\end{array}$ & $\begin{array}{l}\text { World Bank WDI } \\
\text { online database; Beck } \\
\text { et al. (2010) }\end{array}$ \\
\hline & $\begin{array}{l}\text { 'Comprised of private credit as well as } \\
\text { credit to the public sector (central and } \\
\text { local governments and public enterprise) } \\
\text { as a share of GDP, average over } \\
\text { 2000-20IO' }\end{array}$ & $\begin{array}{l}\text { World Bank WDI } \\
\text { online database; Beck } \\
\text { et al. (20Iо) }\end{array}$ \\
\hline $\begin{array}{l}\text { Stock market } \\
\text { capitalisation }\end{array}$ & $\begin{array}{l}\text { 'Value of listed companies' shares on } \\
\text { domestic exchanges as a share of GDP, } \\
\text { average over 2000-20I0' }\end{array}$ & $\begin{array}{l}\text { World Bank WDI } \\
\text { online database; Beck } \\
\text { et al. (20Iо) }\end{array}$ \\
\hline $\begin{array}{l}\text { Stock market value } \\
\text { traded }\end{array}$ & $\begin{array}{l}\text { 'Total value of domestic shares traded (on } \\
\text { domestic exchanges) during the period as } \\
\text { a share of GDP, average over 2000-2010' }\end{array}$ & $\begin{array}{l}\text { World Bank WDI } \\
\text { online database; Beck } \\
\text { et al. (20IO) }\end{array}$ \\
\hline $\begin{array}{l}\text { Stock market } \\
\text { turnover ratio }\end{array}$ & $\begin{array}{l}\text { 'Ratio of trades in domestic shares divided } \\
\text { by market capitalization, average over } \\
\text { 2000-20I0' }\end{array}$ & $\begin{array}{l}\text { World Bank WDI } \\
\text { online database; Beck } \\
\text { et al. (20IO) }\end{array}$ \\
\hline Creditor rights & $\begin{array}{l}\text { An index of the protection of creditor } \\
\text { rights in 200o. It reflects the ease with } \\
\text { which creditors can secure assets in the } \\
\text { event of bankruptcy. It takes on discrete } \\
\text { values of o (weak creditor rights) to } 4 \\
\text { (strong creditor rights) }\end{array}$ & Djankov et al. (2007) \\
\hline Trade openness & $\begin{array}{l}\text { Sum of exports and imports of goods and } \\
\text { services as a share of GDP in } 2000\end{array}$ & $\begin{array}{l}\text { World Bank WDI } \\
\text { online database }\end{array}$ \\
\hline Financial openness & $\begin{array}{l}\text { Sum of gross stock of foreign assets and } \\
\text { liabilities as a share of GDP in } 2000\end{array}$ & Lane et al. (2007) \\
\hline Legal origins & $\begin{array}{l}\text { Dummy variable that takes a value of I if a } \\
\text { country's legal system is of French, } \\
\text { German or Scandinavian civil law origin } \\
\text { and o otherwise }\end{array}$ & La Porta et al. (2008) \\
\hline Latitude & $\begin{array}{l}\text { Absolute value of the latitude of a country, } \\
\text { scaled between o and I, where o is for the } \\
\text { location of the equator and I is for the } \\
\text { poles }\end{array}$ & La Porta et al. (I999) \\
\hline Tropics & $\begin{array}{l}\text { The percentage of land area classified as } \\
\text { tropical and subtropical based on the } \\
\text { Koeppen-Geiger system }\end{array}$ & Gallup et al. (I999) \\
\hline
\end{tabular}


Table Ar. Continued

\begin{tabular}{|c|c|c|}
\hline Variables & Definitions & Sources \\
\hline Religion variables & $\begin{array}{l}\text { A set of three variables that identifies the } \\
\text { percentage of a country's population in } \\
\text { the I } 98 \text { os that follows Catholic, Muslim } \\
\text { and other religion }\end{array}$ & La Porta et al. (I999) \\
\hline $\begin{array}{l}\text { Ethnic } \\
\text { fractionalisation }\end{array}$ & $\begin{array}{l}\text { An index of ethnic fractionalisation, } \\
\text { constructed as one minus the Herfindahl } \\
\text { index of the share of the largest ethnic } \\
\text { groups. It reflects the probability that two } \\
\text { individuals, selected at random from a } \\
\text { country's population, will belong to } \\
\text { different ethnic groups. The index ranges } \\
\text { from o to I, where the higher the value } \\
\text { the greater the fractionalisation in a } \\
\text { country }\end{array}$ & Alesina et al. (2003) \\
\hline Institutional quality & $\begin{array}{l}\text { An overall indicator of institutional quality } \\
\text { measured as the sum of the six sub- } \\
\text { indices for } 2000 \text { from World Bank } \\
\text { Governance Indicators (WBGI): voice } \\
\text { and accountability; political stability and } \\
\text { absence of violence; government } \\
\text { effectiveness; regulatory quality; rule of } \\
\text { law; and control of corruption. Countries } \\
\text { with higher values on this index have } \\
\text { institutions of greater quality }\end{array}$ & Kaufmann et al. (20IO) \\
\hline Social capital & $\begin{array}{l}\text { Data on trust between individuals in a } \\
\text { given country. Measured by taking the } \\
\text { percentage of a population that answers } \\
\text { 'Yes' to the World Value Survey (WVS) } \\
\text { question 'In general, do you think that } \\
\text { most people can be trusted?' } \\
\text { supplemented by data from the Danish } \\
\text { Social Capital Project, the } \\
\text { Latinobarometro and the Afrobarometer }\end{array}$ & Bjørnskov (2008) \\
\hline $\begin{array}{l}\text { Geographical } \\
\text { isolation }\end{array}$ & $\begin{array}{l}\text { The unweighted average of the time } \\
\text { required to reach the country's capital } \\
\text { along cost-minimising paths }\end{array}$ & Ashraf et al. (20I0) \\
\hline Aerial isolation & $\begin{array}{l}\text { The loss between two points; the } \\
\text { conventional detrimental effect of } \\
\text { isolation }\end{array}$ & Ashraf et al. (2010) \\
\hline
\end{tabular}


Table A2. Descriptive statistics

\begin{tabular}{|c|c|c|c|c|c|}
\hline Variables & Observations & Mean & $\begin{array}{l}\text { Standard } \\
\text { deviation }\end{array}$ & Minimum & Maximum \\
\hline Private credit & I 80 & 0.504 & 0.463 & 0.019 & 2.303 \\
\hline Domestic credit & I 80 & 0.596 & 0.544 & -0.297 & $3 . \mathrm{III}$ \\
\hline $\begin{array}{l}\text { Stock market } \\
\text { capitalisation }\end{array}$ & $\mathrm{I} 24$ & 0.494 & 0.584 & 0.000 & 4.238 \\
\hline $\begin{array}{l}\text { Stock market value } \\
\text { traded }\end{array}$ & I 22 & 0.306 & $0.56 \mathrm{I}$ & 0.000 & $3 \cdot 447$ \\
\hline $\begin{array}{l}\text { Stock market turnover } \\
\text { ratio }\end{array}$ & 122 & 0.434 & $0.56 \mathrm{I}$ & 0.000 & 2.663 \\
\hline Geographical isolation & 68 & $7 \cdot 456$ & I.447 & 5.501 & $\mathrm{I} 2.052$ \\
\hline Aerial isolation & 68 & 7.9 I 8 & I.499 & 6.724 & I3.IOI \\
\hline Creditor rights & $2 \mathrm{I} 6$ & I. 826 & 0.935 & o & 4 \\
\hline Trade openness & I 80 & 0.883 & 0.509 & O.о Iо & $3 \cdot 720$ \\
\hline Financial openness & I 77 & 2.156 & $2.52 \mathrm{I}$ & 0.424 & 23.977 \\
\hline Latitude & 208 & 0.283 & O.I 89 & O.OIIO & 0.8 \\
\hline Tropics & I65 & 0.374 & 0.436 & $\mathrm{o}$ & I \\
\hline Catholic & 207 & 0.320 & 0.360 & o & O.99I \\
\hline Muslim & 207 & 0.219 & 0.353 & $\mathrm{o}$ & 0.999 \\
\hline Protestant & 205 & O.I 45 & 0.233 & o & 0.998 \\
\hline Ethnic fractionalisation & I 88 & 0.440 & 0.258 & o & 0.930 \\
\hline Institutional quality & I 89 & 2.338 & 3.782 & -6.654 & 9.419 \\
\hline Social capital & I I I & 0.262 & O.I 40 & 0.034 & 0.654 \\
\hline Income & I 80 & 8.528 & I.3O4 & $5.56 \mathrm{I}$ & II.I 42 \\
\hline
\end{tabular}


Table $\mathrm{A}_{3}$. Correlation matrix (to add geographical isolation and aerial isolation)

\begin{tabular}{|c|c|c|c|c|c|c|c|c|c|c|c|c|c|c|c|}
\hline Variables & I & 2 & 3 & 4 & 5 & 6 & 7 & 8 & 9 & IO & I I & I 2 & I 3 & I 4 & I 5 \\
\hline Private credit (I) & I.OOO & & & & & & & & & & & & & & \\
\hline $\begin{array}{l}\text { Geographical } \\
\text { isolation }(2)\end{array}$ & 0.468 & I.OOO & & & & & & & & & & & & & \\
\hline Creditor rights (3) & 0.127 & -0.240 & I.OOO & & & & & & & & & & & & \\
\hline Trade openness (4) & 0.125 & O.I37 & O.I38 & I. .000 & & & & & & & & & & & \\
\hline Financial openness ( 5 ) & $0.57 \mathrm{I}$ & 0.255 & -0.063 & 0.180 & I.000 & & & & & & & & & & \\
\hline Latitude (6) & 0.206 & -0.229 & O.I9I & O.I70 & 0.252 & I.000 & & & & & & & & & \\
\hline Tropics (7) & -0.006 & 0.355 & -0.109 & -0.059 & -0.167 & -0.601 & I.OOO & & & & & & & & \\
\hline Catholic (8) & 0.482 & 0.337 & 0.072 & 0.052 & $0.37 \mathrm{I}$ & 0.347 & -0.208 & I.OOO & & & & & & & \\
\hline Muslim (9) & -0.428 & $-0.2 \mathrm{I} 3$ & -0.154 & -0.123 & -0.199 & -0.500 & -0.129 & $-0.4 \mathrm{I} 2$ & I.OOO & & & & & & \\
\hline Protestant (IO) & 0.395 & 0.100 & -0.028 & O.I IO & $0.4 \mathrm{I} 6$ & 0.529 & -0.138 & O.OOI & -0.319 & I.OOO & & & & & \\
\hline Aerial isolation (I I) & 0.028 & O.I95 & O.OI I & 0.035 & -0.190 & -0.382 & 0.709 & $-0.27 \mathrm{I}$ & -0.152 & -O.IIS & I.000 & & & & \\
\hline Domestic credit (I2) & 0.900 & 0.535 & 0.092 & 0.070 & 0.584 & 0.023 & 0.022 & 0.445 & -0.256 & 0.275 & -0.036 & I.000 & & & \\
\hline $\begin{array}{l}\text { Stock market } \\
\text { capitalisation (I3) }\end{array}$ & 0.601 & 0.326 & -0.138 & O.I 47 & 0.710 & -0.078 & -0.019 & 0.095 & 0.026 & $0.3 \mathrm{I} 2$ & -0.045 & 0.579 & I.000 & & \\
\hline $\begin{array}{l}\text { Stock market value } \\
\text { traded (I4) }\end{array}$ & 0.648 & 0.290 & $-0.07 \mathrm{I}$ & -0.092 & $0.59 \mathrm{I}$ & 0.102 & -0.034 & O.I 44 & -0.126 & 0.433 & 0.083 & $0.58 \mathrm{I}$ & 0.802 & 1.000 & \\
\hline $\begin{array}{l}\text { Stock market } \\
\text { turnover ratio (I } 5 \text { ) }\end{array}$ & 0.239 & O.II & $0.07 \mathrm{I}$ & -0.254 & 0.099 & 0.004 & 0.0623 & 0.010 & 0.052 & 0.202 & 0.242 & O.I97 & O.197 & 0.577 & I.000 \\
\hline
\end{tabular}

